\title{
Public health alternatives to incarceration for drug offenders
}

\author{
Nicholas Clark ${ }^{7}$ Kate Dolan ${ }^{2}$ and David Farabee ${ }^{3}$
}

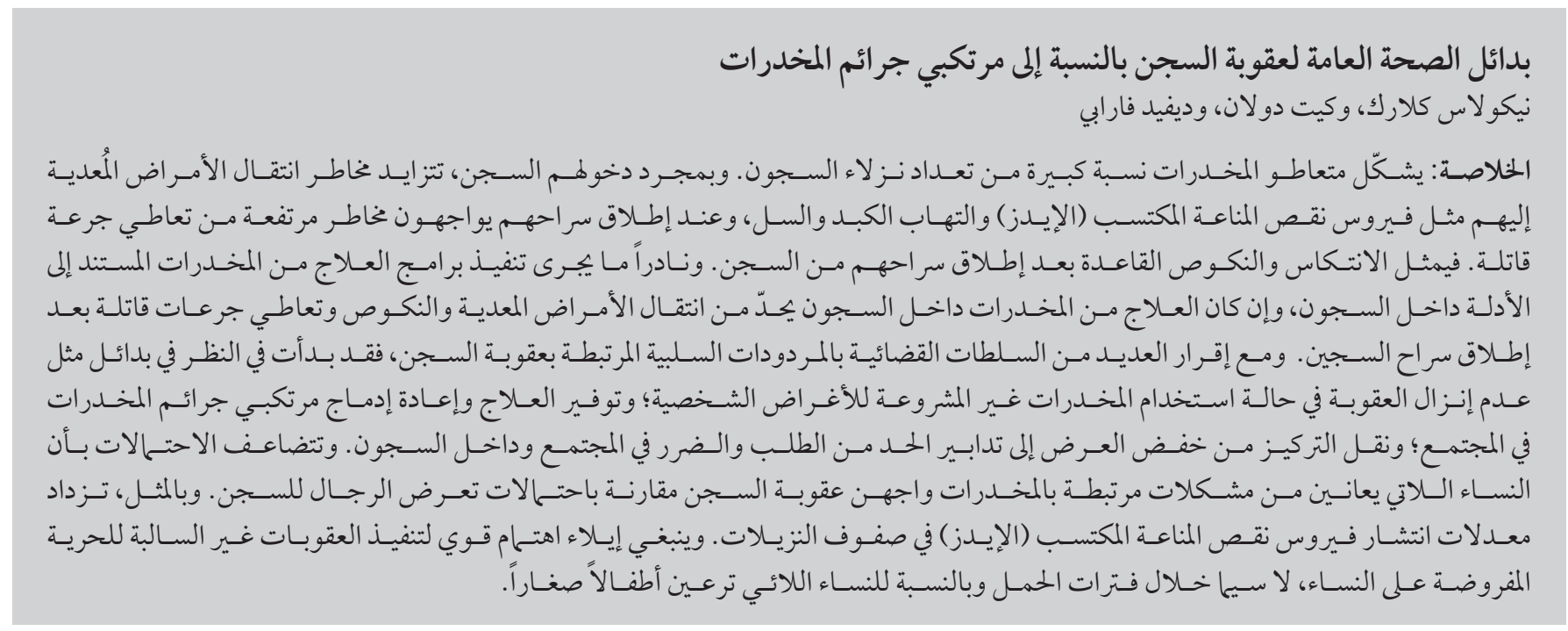

ABSTRACT Drug users are vastly overrepresented in prison populations. Once inside they face increased risks of acquiring infections such as HIV, hepatitis and TB, and on release they face an elevated risk of fatal overdose. Relapse and recidivism are the norm following release from prison. The implementation of evidence-based drug treatment programmes in prison is rare, yet drug treatment in prison reduces the transmission of infections, recidivism and fatal overdose on release. Recognising the negative returns associated with incarceration, many jurisdictions have begun to consider alternatives such as depenalisation of the personal use of illicit drugs, provision of treatment and social reintegration of drug offenders, and a shift in focus from supply reduction to demand and harm reduction measures in the community and in prison. Women with drug problems are twice as likely to have been imprisoned for a drug offence as incarcerated men. Similarly, HIV prevalence is higher among female inmates. Serious attention should be paid to implementation of non-custodial sentences for women, particularly during pregnancy and those with young children.

\section{Alternatives de santé publique à l'incarcération pour les auteurs d'infractions liées à la drogue}

RÉSUMÉ Les toxicomanes sont largement surreprésentés parmi les détenus des prisons. Une fois incarcérés, ils sont d'autant plus exposés au risque de contracter des infections telles que le VIH, I'hépatite et la tuberculose, et à leur libération, ils font face à un risque élevé d'overdose fatale. Les rechutes et la récidive sont la norme après une remise en liberté. La mise en œuvre de programmes de traitement de la toxicomanie reposant sur des données factuelles est rare en milieu carcéral, alors que traiter la toxicomanie en prison permet de réduire la transmission d'infections, la récidive et l'overdose fatale à la sortie. Prenant note des conséquences négatives associées à l'incarcération, de nombreuses juridictions ont commencé à envisager des alternatives telles que la dépénalisation de l'usage personnel de substances illicites, la fourniture d'un traitement et la réinsertion sociale des auteurs d'infractions liées à la drogue, ainsi qu'un changement de priorité, passant de mesures de réduction de l'offre à des mesures de réduction de la demande et d'atténuation des effets nocifs dans la communauté et en prison. Les femmes toxicomanes sont deux fois plus susceptibles d'être emprisonnées pour des infractions liées aux drogues que les hommes. De même, la prévalence du VIH est plus élevée chez les femmes détenues. Une sérieuse attention doit être portée à l'application de peines non privatives de liberté pour les femmes, notamment lorsqu'elles sont enceintes ou en charge de jeunes enfants. 


\section{Introduction}

Globally, at any given time, there are over 10 million people held in prisons and between 2.5 and 3 million of these are held in pre-trial detention. However, turnover in the prison populations is thought to be at least 3 times that with some 30 million individuals being detained and released into the community each year. The vast majority of prisoners are male, with females accounting for less than $10 \%$ of this population (1). Drug offenders account for 3-29\% of prison inmates in the European Union (EU), 4-29\% of inmates in non-EU European countries, $5-53 \%$ of inmates in the Americas and $10-58 \%$ of inmates in Asia/Oceana (2). In the United States of America (USA), between 24\% and $36 \%$ of all heroin addicts pass through the corrections system each year, representing more than 200000 individuals (3).

Incarceration has traditionally been justified on the basis of its assumed effect on deterrence, crime reduction, rehabilitation and retribution. However, there is now a considerable body of evidence indicating that punishment (including imprisonment) provides neither deterrence (4) nor rehabilitation (5), and that the effects on crime reduction are minimal, even in countries with high rates of incarceration (6).

Relapse and re-offence are usual after release from prison. In the USA, for example, drug-use relapse rates (even among those who participate in prisonbased programmes) are more than $80 \%$, and 3-year re-arrest rates are consistently around 70\%. From 1996 to 2006, the population of the USA increased by $13 \%$ and the imprisoned population increased by $33 \%$, yet the proportion of prisoners with a drug problem increased by $43 \%$ (7). Drug-dependent offenders are more likely to return to prison than other offenders. In the USA, over $50 \%$ of drug-dependent inmates have a previous imprisonment compared with $31 \%$ of other inmates. In New South Wales,
$84 \%$ of heroin-dependent inmates were re-imprisoned within 2 years of release, compared to $44 \%$ of all prisoners (8). Australian drug injectors reported an average of 5 imprisonments (9). These high rates confirm that most drug offenders do not receive treatment while in prison nor are they being referred to treatment on release.

Although drug use tends to occur at a lower level in prison than in the community, the infectious disease risks are often higher, as inmates share syringes when they cannot access sterile ones (nor can they access products to sterilize them). As a result, having one or more prior incarceration is a major risk factor for having HIV and hepatitis C. In fact, among injection drug users in Tehran, Islamic Republic of Iran, a history of shared needles in prison was found to be the strongest predictor of being HIV-positive (10). In two Scottish prisons, $6 \%$ and $25 \%$ of injection drug users reported that they started injecting while in prison (11). The risk of death among people on parole during the first 2 weeks after release from prison is nearly 13 times greater than among individuals of similar demographic background, with drug overdose being the leading cause of death (12).

Recognizing the high cost and negative returns associated with imprisonment, many authorities have begun to consider alternatives. From a public health perspective, such alternatives include:

- Decriminalize personal use of illicit drugs,

- Provide treatment and social reintegration of people with drug use disorders who come into contact with the criminal justice system,

- Move the focus of funding away from supply-reduction measures towards demand- and harm-reduction measures.

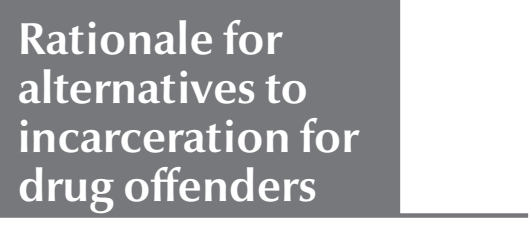

Alternative approaches to imprisonment are consistent with the obligations UN Member States have under the international drug control conventions, as the following details:

- Alternatives to conviction and punishment are permitted in the international drug control conventions and treatment is encouraged. The 3 international drug control conventions each contain a clause that allows for treatment and social reintegration as an alternative to conviction and punishment. The conventions also explicitly mention the need to make treatment available.

- Conviction of minor drug offences does not prevent drug use. Conviction and punishment of minor drug offences does not deter drug use and does not lead to rehabilitation.

- Conviction and punishment of minor drug offences is often disproportionate. The International Narcotics Control Board (INCB) has also reminded Member States of this principle of proportionality in criminal justice and to take the Tokyo rules into consideration (13).

- Conviction and punishment is expensive and causes harm. Imprisonment is more expensive than treatment and uses valuable resources that could be used more effectively for the prevention and treatment of drug use disorders. Increased spending on prisons in the USA, for example, has been shown to correlate with a reduction in spending on education, education being one of the most effective investments a country can make in preventing drug use (14).

- Treatment and social reintegration reduce both drug use and drug-related crime. Treatment of substance use disorders has been consistently 
shown to reduce drug-related crime. The extent of the reduction varies depending on the type of substance use disorder and the type of treatment. In the treatment of opioid dependence, drug use and drug-related crime can be reduced by more than $50 \%$ with the use of opioid maintenance treatment such as methadone (15). Non-dependent drug use can be reduced by brief interventions, while dependent use of cannabis and stimulants can be reduced by more structured psychosocial interventions (16). Overall, most experts agree that treatment of substance use disorders leads to a significant reduction in offending $(17,18)$.

- Treatment for drug use disorders is a cost-effective way to reduce drug use and crime in addition to other benefits. In addition to reducing drug use, treatment of substance use disorders reduces health care problems such as HIV and facilitates employment. Cost-benefit analyses of drug treatment, looking at the effect on health care costs, employment, and government expenditure on social services and crime, have estimated the returns on investment range from
$7: 1$ to $18: 1$, meaning that for every dollar spent on drug treatment, savings of between 7 and 18 dollars are returned $(18,19)$.

\section{Public health alternatives}

\section{Decriminalization}

Countries can decriminalize the personal use of illicit drugs. The international drug control conventions distinguish between "minor" and "serious" drug offences. The accepted interpretation of this phrasing is that minor crimes may be managed entirely by referral to treatment, by education or even simply by admonishment as an alternative to conviction or punishment, whereas serious crimes should result in conviction and punishment, in proportion to other offences in the country.

Thirty countries have reformed their drug policies to permit some form of decriminalization (20). Decriminalizing drug possession and investing in demand and harm reduction services can provide major benefits for public safety and health, including:

- reducing the number of people in prison,

- reducing criminal justice costs and redirecting resources from criminal justice to health systems,

- redirecting law enforcement resources to prevent serious and violent crime,

- reducing unjust racial disparities in drug law enforcement and sentencing, imprisonment and related health characteristics and outcomes,

- minimizing the social exclusion of people who use drugs, and creating a climate in which they are less fearful of seeking and accessing treatment, using harm reduction services and receiving HIV/AIDS services.

Other benefits are: increasing uptake into drug treatment, improving relations between law enforcement and the community, and protecting people from the wide-ranging and debilitating consequences of a criminal conviction and period of imprisonment.

Although countries are free to enforce higher penalties, a public health

\section{Box 1. Effects of reduced sentencing for drug use offences in Portugal}

Drug use has been decriminalized in Portugal since 2001. Possession and sale of proscribed drugs remain illegal in the country but people in possession of drugs for "personal use" (up to a 10-day supply of any drug) are not prosecuted criminally but redirected to a Commission for Dissuasion of Drug Addiction. These committees are composed of a social worker, a doctor and a legal adviser, who assess the level of substance abuse or dependence of the drug user and direct them to appropriate treatment. This measure was accompanied by a greater allocation of resources to treatment (e.g. methadone substitution), harm reduction (e.g. needle and syringe programmes) and prevention interventions.

During the first 6 years of the programme, the committees dealt with approximately 500 cases a month. The number of people undergoing substitution treatment increased from 6040 in 1999 to 14877 in 2003. Lifetime prevalence of substance use increased from $8 \%$ to $12 \%$ between 2001 and 2007 . However, there was a reduction in recent or current use, particularly in the age group 15-24, consistent with a pattern of experimentation and with data showing higher rates of discontinuation. In terms of public health effects, there was a sharp decline in the number of new HIV-positive cases among people who inject drugs (from 1400 in 2000 to 400 in 2006) and a reduction in the number of drug-induced deaths (from around 80 in 2001 to 20 in 2008). In terms of effects on crime, the number of convictions for drug trafficking remained stable in the period of 2001-2005 (around 5000 per year); at the same time, there was a significantly reduced burden on the courts (in 2000 there had been 7592 drug use charges) and on the prison system (prison overcrowding decreased from 119 prisoners per available place down to 101.5 in 2005). 
approach that is consistent with the drug control conventions is to use the flexibility within the conventions to avoid conviction and punishment of people who commit drug offences related to the personal use of illicit drugs. Also, consistent with this approach is the encouragement of all people with substance use disorders who come into contact with the criminal justice system to receive the treatment they need, regardless of the severity of the crime.

\section{Encouraging treatment}

Opportunities for treatment as an alternative to conviction and punishment can occur at many stages in the criminal justice process, starting from initial police contact through to community reintegration after prison. In the same way that treatment and care provided to people with drug use disorders outside the criminal justice sector, treatment is usually as an outpatient, but may include residential therapeutic care for those in need of such services.

Schemes within the criminal justice system that facilitate treatment and care as an alternative to conviction or punishment fall into 4 broad areas depending on their location in the criminal justice process: 1) police diversion schemes, cannabis caution schemes; 2) regular court and probation service based schemes; 3) specialist problemsolving courts, including drug courts; and 4) early release/aftercare of sentenced prisoners.

In combination with these schemes, interaction with the health care system and diversion away from the criminal justice system can occur at numerous points: 1) pre-arrest (i.e. as an alternative to arrest);2) police arrest; 3 ) in police custody and police custody on suspicion of a criminal offence; 4) in the pre-trial process; 5) during the trial process; 6) on sentencing; 7) on entry to prison; 8) in prison; 9) on preparation for release from prison; 10) on release into the community, including while on parole; and 11) on leaving the criminal justice system (either on release from prison, or when the parole period ends).

\section{Drug courts}

A systematic review of the effectiveness of drug courts found that participants have lower re-offence than non-participants; on average re-offence decreased from $50 \%$ to $38 \%$, and can last for up to 3 years. Larger reductions in re-offence were found in adult drug courts that had high graduation rates and those that accepted only non-violent offenders. Juvenile drug courts have substantially smaller effects on re-offence (21).
There are currently more than 2000 drug courts operating in the USA. Programmes also operate in Australia, Canada, United Kingdom and New Zealand. Drug courts vary in how they manage their caseloads, in the ancillary services they offer and in the testing and sanction schedules they apply. What they all have in common is the provision of ongoing supervision from a judge, with offenders appearing before the judge for regularly scheduled updates. The drug court movement has been very successful. Many evaluations suggest that this is an effective approach to managing offenders in the community (22), although most of the support comes from non-randomized evaluations. The most rigorous evaluation, using a randomized, intent-to-treat design was conducted on the Baltimore City Drug Court in Maryland, USA. A 1-year follow-up showed significantly lower levels of drug use and fewer arrests among those assigned to the drug court versus those in the control situation. By the time of the 3-year follow-up, these differences were no longer significant, although trends still favoured the drug court participants $(23,24)$.

\section{Box 2. Drug treatment courts in Australia}

The Australian state of New South Wales first created drug courts in 1999. Offenders may be directed to drug courts if they meet the eligibility criteria regarding the kind of offence committed (drug supply and sexual assault prevent inclusion) and proven dependence on drugs. The drug court offers a treatment programme as an alternative to imprisonment on condition that the offender pleads guilty. Compliance with treatment is strictly regulated through urine testing and regular reports to the court. The 1-year programme includes a stabilization phase (3 months), including access to opioid substitution therapy if needed; a consolidation phase ( 3 months) to develop life and job skills; and a reintegration phase ( 6 months) where the offender should reintegrate into the community and secure employment.

An evaluation has shown that people who entered the programme were less likely to have further convictions, especially if they successfully completed it (the likelihood of a subsequent conviction for crimes against a person was $23 \%$ for the control group and $9 \%$ for those who completed treatment; for crimes against property, the likelihoods were $44 \%$ and $39 \%$ respectively). Cost-benefit analyses also showed that drug courts were as cost-effective as conventional sanctions in delaying time to the first offence and more cost-effective in reducing the frequency of subsequent offending. 


\section{Community supervision and treatment}

Awareness of the high prevalence of drug use among criminal offenders prompted a number of large-scale efforts in the USA to use the power of legal pressure to encourage substanceabusing offenders to enter treatment. The most common form was "diversion," in which adults convicted of nonviolent drug possession offences have the option of participating in drug treatment in the community instead of imprisonment or probation without treatment. Unfortunately, evaluations of these efforts showed that these diverted offenders were more likely to be rearrested for a drug crime than other participants referred to treatment by the criminal justice system (25) or similar offenders charged prior to this initiative (26). One of the most important findings to emerge from these evaluations was that requiring the existing treatment system to provide services for drug users of all severity levels resulted in a misallocation of resources. Most importantly, attempting to treat everyone with a drug use history meant many offenders with serious drug use disorders received inadequate care. Moreover, lax and inconsistent enforcement of these referrals allowed offenders to ignore treatment referrals - and even scheduled probation appointments and drug testing - with no penalties. These experiences made it clear that effective management of drug offenders requires close monitoring and consequences for non-compliance. It also became clear that targeting treatment resources on those with the highest need is more effective than offering low levels of treatment for everyone. This can be construed as a continuum of services ranging from random drug testing coupled with gradually increasing sanctions to residential care with the full complement of ancillary medical and social services.

\section{Drug treatment for prisoners}

Given the large number of injection drug users and the fact many inmates start injecting in prison and are at risk of injecting-related harm, the prison setting would seem the logical place to provide drug treatment. With heroin often the main drug injected in prison, it follows that medication assisted treatment of opioid dependence (MATOD) would be the ideal treatment. MATOD uses medicines such as methadone or buprenorphine and psychosocial support. MATOD has been shown to reduce injecting and syringe sharing (27) and hepatitis C transmission $(28,29)$ in prison and mortality after release from prison (29). MATOD reduced post-release criminal activity (30) and re-imprisonment by up to $20 \%$ among a group with a high rate of re-imprisonment (31).

Cognitive behavioural therapy (CBT) has been shown to reduce rearrest $(32,33)$ and re-imprisonment (34). It has also been identified as an effective treatment for criminal behaviour and alcohol and drug use problems in offenders $(35,36)$. Prisonbased cognitive behavioural therapy

\section{Box 3. Effect of expanding treatment as a means of reducing drug related crime in the United Kingdom}

In 2001 the United Kingdom government created the National Treatment Agency for Substance Misuse (NTA) to "improve the availability, capacity and effectiveness of drug treatment in England"; one of the key objectives was to reduce drug-related crime. The agency oversaw the implementation of a new drug treatment system based on the best available evidence according to experts in the field of substance abuse.

The introduction of treatment programmes overseen by the NTA has led to a large increase in the number of drug users in treatment, from around 100000 in 2001 to 210815 in 2008/09. The new system was also more efficient, with shorter waiting times for treatment: in 2001 the average waiting time for an appointment was 9 weeks while in 2008/09 it was 5 days. A study on the effect of treatment on outcomes (Drug Treatment Outcomes Research Study, 2009) showed that the greatest reductions in drug use were found in problem drug users: 12 months after the baseline interviews, $49 \%$ of heroin users and $61 \%$ of crack users were no longer using drugs. Treatment also affected risk behaviours such as sharing injecting equipment; of the people who inject drugs who reported sharing at baseline, $77 \%$ had stopped sharing 1 year later. Treatment also had a positive effect on crime: around $40 \%$ of users at the start of the study had committed offences in the previous 4 weeks; this fell to $16 \%$ after 1 year. Interestingly, the study also showed that users referred to treatment by the criminal justice system were as likely to complete treatment successfully as users referred by other sources. The net benefit to society per person undergoing treatment, considering their improved outcomes in terms of health and crime, was $£ 6527$. In addition, for every $£ 1$ invested in drug treatments, $£ 2.50$ are returned to society. A more recent study by the NTA (Estimating the crime reduction benefits of drug treatment and recovery, 2012) estimated that drug treatment prevented approximately 4.9 million crimes in 2010/2011, corresponding to $£ 960$ million in savings to society (including the public, businesses and the justice and health systems). 
(interventions were cost-effective in terms of re-offence (37).

\section{Women in prison}

The number of imprisoned women is increasing in all 5 continents; it increasing by an average of $16 \%$ in the past 6 years (1). In 2012, more than 600000 women and girls were held in prisons worldwide (38). Imprisoned women are twice as likely to have a drug problem as male prisoners and are more likely to have been imprisoned for a drug offence than imprisoned men (39). A global review found HIV prevalence was higher in female than in male inmates in 15 countries, including Afghanistan (4\% versus $1 \%)$ and was lower than male inmates in only 7 countries (40).

Women who are poor and uneducated are more likely to be arrested and less likely to afford legal counsel than men. Alternatives to incarceration for drug-involved women are needed, especially for those in prison for non-violent offences who pose no risk to public safety. Serious attention should be paid to the development and implementation of non-custodial sentences for women, particularly during pregnancy and when they have young children. A study of women seeking treatment in the Islamic Republic of Iran found that they were more likely to have been in prison $(48 \%)$ than in drug treatment (20\%) (41).

\section{Treatment coverage for prisoners}

Although a country may provide drug treatment for inmates, the coverage is often very poor. In 1996, 5 countries provided methadone for prisoners; this increased to 29 countries in 2009 (42), to 41 countries in 2012 (43) and to 43 countries in 2013 (44). Even when a country provides MATOD to inmates, few receive it. A review of 20 countries with prison-based MATOD found less than $10 \%$ of inmates in 17 countries were in treatment (42). An assessment revealed that injecting drug use is known to occur in 148 countries (45).

Of the 2.3 million prison inmates in the USA, 65\% meet the DSM-IV medical criteria for alcohol or other drug abuse and addiction, but only $11 \%$ received treatment for their addictions with less than $1 \%$ of prison budgets spent on treatment (7).

\section{Demand and harm reduction measures}

There needs to be a shift in the focus of funding from supply reduction measures to demand and harm reduction measures. In addition to reducing drug use, treatment of drug use disorders reduces health care problems such as HIV and assists with a return to work. Even within many prison systems, there is a focus on supply-reduction measures at the expense of demand-and harm-reduction measures. An Australian study found that despite an extensive use of drug searches and urinalysis, the detection of drugs was modest for both strategies. The most commonly used drug was cannabis with the detection of drugs such as amphetamines and heroin being very low. Several millions of dollars are spent on these supply-reduction measures, while many inmates go untreated for drug dependency (46).

\section{Conclusion}

An imprisonment-based response to drug use in society is costly, is associated with significant public health risks, particularly for women who use drugs, and is of questionable benefit to public safety. Opportunities for alternatives to imprisonment exist at every step in the criminal justice process, and examples can be found from different authorities around the world for each of these. Such examples demonstrate the feasibility of such approaches, but also the challenges in setting up effective programmes. Further work is needed to clearly evaluate the relative effect on public health and public safety of the different approaches.

\section{Funding: None.}

Competing interests: None declared.

\section{Box 4. Aftercare in Canada}

In response to the high levels of drug abuse among women offenders in Canadian correctional services, the Women Offenders Substance Abuse Program was established in 2003 to provide treatment and support during and after imprisonment. The treatment programme consists of 4 modules: education and engagement; intensive therapeutic treatment; relapse prevention and maintenance; and community relapse prevention and maintenance (CRPM). The first 3 models are offered to women during imprisonment while CRPM is offered after release, while under supervision in the community.

Women who participated in the CRPM module had significantly better outcomes than those who only participated in the modules in prison. Only $5 \%$ of women who had participated in CRPM had returned to prison 1 year later, compared to $38 \%$ of those who had no exposure to CRPM. The reasoning for this approach is that offenders in prison are sheltered from many of the environmental factors that trigger offending and drug abuse and continuing therapy after release can be particularly helpful in preventing relapses. 


\begin{tabular}{|c|c|c|c|c|}
\hline & Police referral & $\begin{array}{l}\text { Regular court or probation-based } \\
\text { services }\end{array}$ & Drug courts & Aftercare \\
\hline $\begin{array}{l}\text { Point of } \\
\text { intervention }\end{array}$ & $\begin{array}{l}\text { Pre-arrest, pre- } \\
\text { booking, or pre- } \\
\text { court appearance }\end{array}$ & $\begin{array}{l}\text { Pre-plea/pre-trial, post-plea/post- } \\
\text { trial, or post-sentence }\end{array}$ & $\begin{array}{l}\text { Pre-plea/pre-trial, post- } \\
\text { plea/post-trial, or post- } \\
\text { sentence }\end{array}$ & $\begin{array}{l}\text { Post } \\
\text { imprisonment/ } \\
\text { early release }\end{array}$ \\
\hline $\begin{array}{l}\text { Keyfeatures: } \\
\text { who initiates the } \\
\text { process? }\end{array}$ & $\begin{array}{l}\text { - Police refer } \\
\text { participant } \\
\text { to education, } \\
\text { assessment or } \\
\text { treatment. It can } \\
\text { either be based on } \\
\text { police discretion } \\
\text { or be a standard } \\
\text { procedure that first } \\
\text { arrest gets plan A, } \\
\text { second arrest gets } \\
\text { plan B, third arrest } \\
\text { gets plan C. }\end{array}$ & $\begin{array}{l}\text { - Participant is referred to } \\
\text { treatment by court or probation } \\
\text { service. The process is initiated } \\
\text { by key criminal justice persons } \\
\text { (magistrate, judge, court worker, } \\
\text { prosecution, defence lawyer) } \\
\text { - Court oversight is generally } \\
\text { limited to reports from the } \\
\text { treatment sector, although the } \\
\text { participant is required to appear } \\
\text { in court for specific events such } \\
\text { as treatment non-compliance or } \\
\text { sentencing } \\
\text { - Health and justice have clearly } \\
\text { defined and separate roles } \\
\text { - Communication between } \\
\text { teams may be provided by a } \\
\text { coordinator } \\
\text { - Court may pay for treatment, if } \\
\text { necessary }\end{array}$ & $\begin{array}{l}\text { - Judge/magistrate with } \\
\text { specialist knowledge } \\
\text { is the leader of a } \\
\text { multidisciplinary drug } \\
\text { treatment service } \\
\text { - Participants are required } \\
\text { to appear in court } \\
\text { regularly } \\
\text { - Standardized regimens of } \\
\text { treatment are commonly } \\
\text { used and frequent urine } \\
\text { testing may be required } \\
\text { - Rewards for compliance } \\
\text { with programme } \\
\text { conditions \& sanctions } \\
\text { for non-compliance } \\
\text { to effect behavioural } \\
\text { change }\end{array}$ & $\begin{array}{l}\text { - Services assess } \\
\text { individual } \\
\text { needs of } \\
\text { participants } \\
\text { prior to release } \\
\text { from prison and } \\
\text { provide access } \\
\text { to a variety of } \\
\text { medical and } \\
\text { psychosocial } \\
\text { services within } \\
\text { the community, } \\
\text { including } \\
\text { ongoing drug } \\
\text { treatment }\end{array}$ \\
\hline Advantages & $\begin{array}{l}\text { - Time and cost } \\
\text { savings on criminal } \\
\text { justice processing } \\
\text { - Police in a good } \\
\text { position to } \\
\text { coordinate referral } \\
\text { to appropriate } \\
\text { services } \\
\text { - The offender } \\
\text { presents at a time } \\
\text { of crisis when } \\
\text { motivated to enter } \\
\text { treatment }\end{array}$ & $\begin{array}{l}\text { - Time and cost savings on criminal } \\
\text { justice processing } \\
\text { - Large volume of participants } \\
\text { processed } \\
\text { - Regular courts can process } \\
\text { individuals } \\
\text { - Participants chose their own } \\
\text { treatment }\end{array}$ & $\begin{array}{l}\text { - Judge-led } \\
\text { multidisciplinary } \\
\text { decision-making } \\
\text { - Authority figure of } \\
\text { judge instrumental in } \\
\text { therapeutic change } \\
\text { - Close supervision of } \\
\text { participants } \\
\text { - Swift application of } \\
\text { sanctions for non- } \\
\text { compliance }\end{array}$ & $\begin{array}{l}\text { - Facilitates } \\
\text { reintegration } \\
\text { into the } \\
\text { community }\end{array}$ \\
\hline Disadvantages & $\begin{array}{l}\text { - Police discretion } \\
\text { may be open to } \\
\text { misuse }\end{array}$ & $\begin{array}{l}\text { - Objectives of justice and } \\
\text { treatment services may diverge } \\
\text { - Judicial oversight may be limited } \\
\text { - Communication between justice } \\
\text { and health services may be } \\
\text { limited } \\
\text { - Rewards for compliance or } \\
\text { sanctions for non-compliance } \\
\text { may be delayed or inadequate } \\
\text { - Judicial discretion may be open } \\
\text { to misuse }\end{array}$ & $\begin{array}{l}\text { - Judges may lack } \\
\text { specialist expertise in } \\
\text { clinical decision-making } \\
\text { - There may be blurring } \\
\text { of distinctions between } \\
\text { criminal justice and } \\
\text { treatment } \\
\text { - Resource intensive and } \\
\text { potentially costly to } \\
\text { establish } \\
\text { - Relatively few offenders } \\
\text { processed } \\
\text { - Participants have less } \\
\text { choice in the treatment } \\
\text { method }\end{array}$ & $\begin{array}{l}\text { - Coordination } \\
\text { is required } \\
\text { to ensure } \\
\text { individualized } \\
\text { treatment and } \\
\text { rehabilitation } \\
\text { needs are met } \\
\text { and maintained } \\
\text { over time } \\
\text { - Not a complete } \\
\text { alternative to } \\
\text { conviction or } \\
\text { punishment }\end{array}$ \\
\hline
\end{tabular}

\section{References}

1. Walmsley R. World Female Imprisonment List (second edition) Women and girls in penal institutions, including pre-trial detainees/remand prisoners: London: International Centre for Prison Studies; 2012.

2. Bewley-Taylor D, Hallam C, Allen R. The incarceration of drug offenders: an overview. London: King's College; 2009.
3. Boutwell AE, Nijhawan A, Zaller N, Rich JD. Arrested on heroin: a national opportunity. J Opioid Manag. 2007;3:328-32.

4. Torny M. The future of imprisonment. Oxford: Oxford University Press; 2004.

5. Gendreau P, Cullen FT, Goggin C. The effects of prison sentences on recidivism. Ottawa: Solicitor General Canada; 1999. 
6. Kuziemko I, Levitt SD. An empirical analysis of imprisoning drug offenders. J Public Econ. 2004;88(9):2043-66.

7. CASA. The National Center on Addiction and Substance Abuse at Columbia University. Behind bars II: substance abuse and America's prison population. New York: CASA; 2010.

8. Steering Committee for the Review of Government Service Provision. Report on government services. Canberra: Productivity Commission; 2010.

9. Dolan K, Wodak A, Hall W. HIV risk behaviour and prevention in prison: a bleach programme for inmates in NSW. Drug Alcohol Rev. 1999;18(2):139-43.

10. Zamani S, Kihara M, Gouya MM, Vazirian M, Nassirimanesh B, Ono-Kihara M, et al. High prevalence of HIV infection associated with incarceration among community-based injecting drug users in Tehran, Iran. J Acquir Immune Defic Syndr. 2006;42(3):342-6.

11. Gore SM, Bird AG, Ross AJ. Prison rites: starting to inject inside. BMJ. 1995;311:1135.

12. Binswanger IA, Stern MF, Deyo RA, Heagerty PJ, Cheadle A, Elmore JG, et al. Release from prison: a high risk of death for former inmates. N Engl J Med. 2007;356(2):157-65.

13. United Nations Office on Drugs and Crime (UNODC). INCB Annual report. New York: UNODC; 2007 (http://www. incb.org/incb/en/publications/annual-reports/annual-report-2007.html).

14. United Nations Office on Drugs and Crime UNODC). Why promote prison reform? New York: UNODC; 2016 (https://www. unodc.org/unodc/en/justice-and-prison-reform/prisonreform-and-alternatives-to-imprisonment.html).

15. World Health Organization. Guidelines for the psychosocially assisted pharmacological treatment of opioid dependence. Geneva: World Health Organization; 2009 (http://www. who.int/substance_abuse/publications/Opioid_dependence_guidelines.pdf?ua=).

16. World Health Organization. mhGAP, Intervention guide for mental, neurological and substance use disorders in nonspecialized health settings. Geneva: World Health Organization; 2010 (http://www.who.int/mental_health/publications/ mhGAP_intervention_guide/en/).

17. Prendergast ML, Podus D, Chang E, Urada D. The effectiveness of drug abuse treatment: a meta-analysis of comparison group studies. Drug Alcohol Depend. 2002;67(1):53-72.

18. Godfrey C, Stewart D, Gossop M. Economic analysis of costs and consequences of the treatment of drug misuse: 2-year outcome data from the National Treatment Outcome Research Study (NTORS). Addiction. 2004;99(6):697-707.

19. Rydell, CP, Everingham SS. Controlling cocaine: supply versus demand programs (Vol. 331). Santa Monica: Rand Corporation; 1994.

20. Strathdee SA, Beletsky L, Kerr T. HIV, drugs and the legal environment. Int J Drug Policy. 2015 Feb;26 Suppl 1:S27-32.

21. Mitchell O, Wilson DB, Eggers A, MacKenzie DL. Assessing the effectiveness of drug courts on recidivism: a meta-analytic review of traditional and non-traditional drug courts. J Crim Justice. 2012;40(1):60-71.

22. Belenko S. Research on drug courts: a critical review. Natl Drug Court Inst Rev. 1998;1(1):1-42.

23. Gottfredson D, Exum L. The Baltimore City Drug Court: oneyear results from a randomized study. J Res Crime Delinq. 2002;39:337-56.

24. Gottfredson DC, Kearley B, Najaka SS, Rocha C. The Baltimore City Drug Treatment Court: three-year self-report outcome study. Eval Rev. 2005;29(1):42-64.
25. Farabee D, Hser YH, Anglin MD, Huang D. Recidivism among an early cohort of California's Proposition 36 offenders. Criminol Public Policy. 2004;3(4):501-22.

26. Urada D, Longshore D. SACPA Offenders. Evaluation of the substance abuse and crime prevention act: final report. Sacramento: California Department of Alcohol and Drug Programs; 2007.

27. Larney S. Does opioid substitution treatment in prisons reduce injecting-related HIV risk behaviours? A systematic review. Addiction. 2010;105(2):216-23.

28. Marco A, Gallego C, Caylà JA. Incidence of Hepatitis C Infection among Prisoners by Routine Laboratory Values during a 20-Year Period. PLoS One. 2014;9(2):e90560. 10.1371/journal. pone.0090560

29. Dolan KA, Shearer J, White B, Zhou J, Wodak A. Four-year follow-up of imprisoned male heroin users and methadone treatment: mortality, re-incarceration and hepatitis $\mathrm{C}$ infection. Addiction. 2005;100(6):820-8.

30. Kinlock TW, Gordon MS, Schwartz RP, Fitzgerald TT, O'Grady $\mathrm{KE}$. A randomized clinical trial of methadone maintenance for prisoners: Results at 12 months post release. J Subst Abuse Treat. 2009;37(3):277-85.

31. LarneyS, Toson B, Burns L, Dolan K. Effect of prison-based opioid substitution treatment and post-release retention in treatment on risk of re-incarceration. Addiction. 2012;107(2):372-80.

32. Burnette KD, Prachniak K, Leonard A, Robinson KD, Swan ES, Little GL. Effects of moral reconation therapy on female offenders in a prison-based therapeutic communitiy. Cog Behav Treat Review. 2005;14(3):1-4.

33. Golden L. Evaluation of the efficacy of a cognitive behavioral program for offenders on probation: thinking for a change. Doctoral dissertation, University of Texas Southwestern Medical Center at Dallas; 2002.

34. Little GL, Robinson KD, Burnette KD. Cognitive-behavioral treatment of felony drug offenders: a five-year recidivism report. Psychol Rep. 1993;73(3 Pt 2):1089-90.

35. Harada T. The randomized controlled trial of the prison-based Japanese Matrix program (J-MAT) for methamphetamine abusers. Nihon Arukoru Yakubutsu Igakkai Zasshi. 2012;47(6):298307.

36. Blacker J, Watson A, Beech AR. A combined drama-based and CBT approach to working with self-reported anger aggression. Crim Behav Ment Health. 2008;18(2):129-37.

37. Aos S, Lee S, Drake E, Pennucci A, Klima T, Miller M, et al. Return on investment: Evidence-based options to improve statewide outcomes (Document 11-07-1201). Olympia (WA): Washington State Institute for Public Policy; 2011.

38. Walmsley R. World prison briefs. International Centre for Prison Studies; 2011 (http://www.prisonstudies.org/info/ worldbrief/wpb_stats.php, accessed 22 February 2012).

39. Lakobishvili E. Cause for alarm: the incarceration of women for drug offences in Europe and Central Asia, and the need for legislative and sentencing reform: London: Harm Reduction International; 2012.

40. Dolan K. HIV prevalence in prison: a global overview. A Global overview. The 20th International AIDS Conference, 19-25 July 2014, Melbourne, Australia.

41. Dolan K, Salimi S, Nassirimanesh B, Mohsenifar S, Mokri A. The establishment of a methadone treatment clinic for women in Tehran, Iran. J Public Health Policy. 2011;32:219-30.

42. Larney S, Dolan K. A literature review of international implementation of opioid substitution treatment in prisons: Equivalence of care? Eur Addict Res. 2009b;15:107-12. 
43. Harm Reduction International. The Global State of Harm Reduction. Towards an integrated response. London: Harm Reduction International; 2012.

44. Dolan K. HIV services in prison: A Global overview. The 20th International AIDS Conference, 19-25 July 2014, Melbourne, Australia.
45. Mathers et al. (2008). Global epidemiology of injecting drug use and HIV among people who inject drugs: a systematic review. 372 (9651) 1733-1745.

46. Dolan K, Rodas A. Detection of drugs in Australian prisons: supply reduction strategies. Int J Prison Health. 2014;10(2):111-7. 